\author{
$\mathrm{KEIO/KYOTO} \mathrm{JOINT}$ \\ GLOBAL CENTER OF EXCELLENCE PROGRAM \\ Raising Market Quality-Integrated Design of "Market Infrastructure"
}

KEIO/KYOTO GLOBAL COE DISCUSSION PAPER SERIES

\author{
DP2010-006
}

\title{
Do Education Vouchers Prevent Dropout at Private High Schools? Evidence from Japanese Policy Changes
}

\author{
Hideo Akabayashi* \\ Hiroko Araki**
}

\begin{abstract}
Although education voucher programs for students attending private high schools have existed in Japan for decades, to date there have been no studies that examine their effectiveness. In this study, we estimate the programs' preventative effect on dropout by using school-track level (academic or vocational) panel data covering all high schools in northern Japan. Prefectural governments have faced increasing dropout rates stemming from financial difficulties, and expanded the scope and amount of their private high school tuition support programs since the late 1990s. We use this variation to identify the effect of tuition support on students' dropout decisions, controlling for initial academic ability of students entering the schools and unobservable school-track effects. We also apply the instrumental variable method to account for the possible endogeneity of policy changes. Our results suggest that increasing tuition support is particularly effective in preventing the dropout of private high school students on nonacademic tracks.

*Hideo Akabayashi

Keio University, hakab@econ.keio.ac.jp. Corresponding author.

**Hiroko Araki

Keio University, hiroco.araki@gmail.com
\end{abstract}

KEIO/KYOTO JOINT GLOBAL COE PROGRAM

Raising Market Quality-Integrated Design of "Market Infrastructure"

Graduate School of Economics and Graduate School of Business and Commerce,

Keio University

2-15-45 Mita, Minato-ku, Tokyo 108-8345, Japan

Institute of Economic Research,

Kyoto University

Yoshida-honmachi, Sakyo-ku, Kyoto 606-8501, Japan 


\title{
Do Education Vouchers Prevent Dropout at Private High Schools? Evidence from Japanese Policy Changes*
}

\author{
Hideo Akabayashi ${ }^{\dagger}$ \\ Hiroko Araki
}

$2010 / 09 / 14$

\begin{abstract}
Although education voucher programs for students attending private high schools have existed in Japan for decades, to date there have been no studies that examine their effectiveness. In this study, we estimate the programs' preventative effect on dropout by using school-track level (academic or vocational) panel data covering all high schools in northern Japan. Prefectural governments have faced increasing dropout rates stemming from financial difficulties, and expanded the scope and amount of their private high school tuition support programs since the late 1990s. We use this variation to identify the effect of tuition support on students' dropout decisions, controlling for initial academic ability of students entering the schools and unobservable school-track effects. We also apply the instrumental variable method to account for the possible endogeneity of policy changes. Our results suggest that increasing tuition support is particularly effective in preventing the dropout of private high school students on nonacademic tracks.
\end{abstract}

Key words: Private School Voucher, Secondary Education, High School Dropout, Japanese Education Policy, Tuition Support

JEL codes: I22, I28, H75

\footnotetext{
* We would like to thank the Japan Private High School Federation for generously providing us with the data. We are grateful to Ryuichi Tanaka, Daiji Kawaguchi, Atsushi Yoshida, Hide Ichimura, Cory Koedel, and participants of seminars at Kansai Labor Research Group, 2008 JEA, 2010 WEAI, GRIPS, MEXT, and RIETI. This research was financially supported by Keio University and the Grant-in-Aid for Scientific Research (A 20243020). The views expressed in this paper are those of the authors and do not necessarily reflect the positions or policies of the organizations mentioned above. All the remaining errors are ours.

† Keio University, hakab@econ.keio.ac.jp. Corresponding author.

${ }^{\star}$ Keio University, hiroco.araki@gmail.com
} 


\section{Introduction}

Since the serious recession stemming from the global financial crisis of autumn 2008, preventing high school students from dropping out because of financial reasons has become an important policy agenda of the governments. In the 2009 general election, the Democratic Party of Japan (DPJ) won a landslide victory with a campaign promise to make public high schools free of charge and to reduce tuition at private high schools. In March 2010, the new Hatoyama administration passed a law that implemented this promise, and therefore Japan now has a free public high school system for the first time in its history.

Although the expansion of tuition support programs for both public and private high school students has been one of the most pressing issues in Japanese secondary education, we do not yet know how much this policy reform will truly help high school students experiencing financial difficulties to stay in school.

In this study, we evaluate the effect of older tuition support programs for private high school students on students' dropout behavior. Such programs have existed for decades in Japan, but increases in high school dropout because of family financial difficulties have been of particular concern since the economic bubble burst in this country in the mid-1990s. Responding to rising high school dropout rates, prefectural governments have expanded the scope of existing tuition support programs and created new programs where they did not previously exist. These programs aim to reduce private high school tuition for students from low-income families and are frequently referred to as Subsidies to Reduce Private High School Tuition (SRPHST, or Shiritsu Koutougakko Jugyouryoutou Keigen Hojokin). Japan has, therefore, effectively had a long history of private school voucher programs at the prefectural level. ${ }^{1}$

${ }^{1}$ In Japan, there have been subsidies, called Shigaku-Josei, from the central and local governments to private schools that abide by certain regulations since 1975, although the amount of the subsidy has not been directly linked to enrollment. The SRPHST programs that we analyze here directly reduce the tuition paid by families of eligible students and thus fit the definition of private school voucher programs more strictly. 
However, to our knowledge, there have not yet been any systematic discussions or quantitative studies that examine the degree to which students continued studying at high school with the support of SRPHST programs or the costeffectiveness of such programs.

The educational outcome we focus on is the dropout rate. We estimate the preventative effect of SRPHST programs on private high school student dropout by using a set of school, track (academic or vocational), and grade-level panel data, covering all full-time high schools in eight prefectures in northern Japan (Tohoku and Hokuriku areas). For the period between 1988 and 2006, we calculate the dropout rate of each school-track-grade group from yearly changes in enrollments and we estimate the effect of policy changes in each prefecture on the average dropout rate at private high schools relative to the average dropout rate at public high schools. This identification strategy is justified, because there has been a wide variation in the eligibility for and the amount of SRPHST grants across prefectures and across years, while there has been little change in the eligibility for and the amount of public high school tuition support.

We use a linear fixed effect model that controls for unobservable school-track effect. We also employ an instrumental variable (IV) estimation in order to account for the possible endogeneity of policy changes. To address a possible selection bias due to changes in student characteristics brought about by policy reforms, we control for the initial average ability of students entering both private and public high schools.

Our main result is that an increase in tuition support significantly prevents the dropout of students in nonacademic tracks in private high schools, but does not have a similar effect for students in academic tracks, given the same level of initial ability. To evaluate the programs' cost-effectiveness, we also performed a 
back-of-the-envelope cost-benefit analysis of the programs by using regional average earnings data by educational achievement and age group. We found that the internal rate of return of current SRPHST programs is roughly $8.53 \%$ for males and $14.20 \%$ for females. ${ }^{2}$

\section{Institutional Background}

\subsection{Overview of High School Dropout in Japan}

Japan has a compulsory national educational policy that requires students to attend six years of elementary school and three years of junior high school (which is equivalent to grades 7-9 in the U.S.). After finishing junior high school, students can choose whether to attend three-year high school (equivalent to grades 10-12 in the U.S.), although today, 97\% of junior high school graduates immediately advance to the high school level (MEXT 2009). ${ }^{3}$

High schools can be categorized on the basis of three dimensions: establishment (public, national, or private), class time (day/full time or evening/night/part time), and curriculum (general/academic, vocational, or integrated). Most public high schools are established and financed by prefectural governments, equivalent to state governments in the U.S., and basic high school policies such as school attendance zones, entrance examinations, tuition and fees, and tuition waivers are controlled by the prefectural boards of education. Tuition support programs for private high school students are also implemented at the prefectural level.

Figure 1 shows changes in the number of high school dropouts and dropout rates in Japan based on official

\footnotetext{
${ }^{2}$ To evaluate the rate of return more precisely, more detailed individual micro-data on wage and educational background is required. Therefore, our cost-benefit evaluation should be considered only as an exercise that should be refined in the future research.

${ }^{3}$ In 2009 , there were 5,472 high schools in Japan, of which 1,321 were private (24.1\%). In terms of the number of students, $29.2 \%$ of high school students attended private schools, $97.0 \%$ students were enrolled full-time, and among the full-time students, $72.3 \%$ of students attended schools with a general curriculum.
} 
statistics from 1982 to 2006 (MEXT 2008). The national average high school dropout rate increased from the mid-1990s, turned downward around 2000, and has hovered around $2.0 \%$ since then. The average dropout rate at private high schools has been consistently higher than that at public high schools. The government report also shows that the percentage of students who dropped out because of "financial issues" or "family problems" is $10.1 \%$ at private high schools, nearly 1.5 times higher than that for public high schools, $6.8 \%$. Furthermore, the percentage of dropouts due to "employment" is $6.9 \%$ at private schools and $16.7 \%$ at public schools. The rate of dropouts caused by "school transfer" is $17.2 \%$ at private schools and $7.8 \%$ at public schools, and it is commonly due to the transfer of students from private high schools to public high schools that are less expensive. These figures show that a significant number of private high school students appear to drop out for financial reasons every year.

\section{-Figure 1-}

\subsection{Tuition Support Programs for Private High School Students in Japan}

In response to public concerns about the number of private high school students who were forced to leave school because of their parents' income loss or unemployment, a number of prefectures expanded their SRPHST programs in the late 1990s. These days, in most prefectures, eligible applicants for SRPHST programs are usually the students whose families receive social welfare payments or meet other specific criteria. These criteria, however, vary across prefectures. For instance, there are a few local governments that have made students bereaved by the death of their guardians in automobile accidents eligible for their SRPHST programs.

According to data from the Japan Private High School Federation, the average SRPHST grant per recipient 
student was 52,841 yen in 1992; this increased to 111,364 yen in 2002, nearly doubling in 10 years. More importantly, since SRPHST policy changes have been determined at each prefecture's discretion, the amount of grants and their associated eligibility criteria have heterogeneously changed across prefectures.

In this study, we use this regional variation in SRPHST programs to estimate the effect of the tuition reduction on students' dropout behavior. Our data is school-track-grade level panel data, covering nearly all full-time public and private high schools in eight northern prefectures between 1988 and 2006. This data period is ideal for our analysis, since nearly all the prefectures enhanced their SRPHST programs in response to severe fluctuations in the economy during the period.

\subsection{Comparison with Previous Literature}

School choice and voucher programs have become a pivotal education policy in countries that aim to promote competition between private and public schools. Private school vouchers would reduce private school tuition and thus provide children from poor families with a chance to choose a private school. Increased choice may also put pressure on public schools to improve educational quality.

Since the 1990s, various empirical studies based on local policy experiments have been launched in the U.S. and other countries. Previous studies on school choice and education vouchers can be generally classified into two categories, on the basis of their research targets and evaluation method. The first line of research aims to verify whether increased competition among schools through voucher programs, charter schools, or consolidation of school attendance zones leads to better overall educational productivity in the whole area in a general equilibrium sense 
(Hoxby 2000, Bettinger 2005, Akabayashi 2009, Sandstrom and Bergstrom 2005, Hsieh and Urquiola 2005). The

second line of research, which can be called "partial equilibrium" analysis, aims to verify whether the educational productivity of private schools (or "choice schools," created by increased public school choice) is higher than that of the monopolistic public schools. In this line of research, the difference in educational productivity of private (or choice) and public schools is estimated by observing changes in the educational outcome of students who were able to transfer from their assigned public school to a private or a choice school (Rouse 1998, Cullen, Jacob, and Levitt 2006).

Our research falls into the second category. Compared with previous studies, our research has the following unique features. First, we use regional differences in generosity of private school voucher programs in order to assess their impact on students. To our knowledge, there are no studies that have estimated the voucher effect by comparing the in region-wide programs, when each region has its own unique voucher program. Second, our data set covers nearly all public and private high schools. ${ }^{4}$ In this data set, public school systems serve as a clear local baseline trend in the high school dropout rate, since private school vouchers do not directly affect them. ${ }^{5}$ These two features allow us to use a relatively simple research design, in which we compare the difference between the dropout rates in private and public schools in prefectures that increased SRPHST grants with the difference in prefectures that did not. ${ }^{6}$

Angrist et al. (2006), one of the most influential studies in this area, evaluates the effects of a region-wide private school voucher program. They evaluate the effects of a school voucher program for secondary students in Columbia,

\footnotetext{
${ }^{4}$ Although our data covers all schools in the regions, the share of private schools in northern Japan is so small that it is not easy to expect any visible general equilibrium (competition) effects in the data. Estimation of the general equilibrium effects is left for future work.

${ }^{5}$ The share of private high schools in the regions of our sample is very small, as we shall see. Therefore, we assume that changes in unobserved factors due to the selection of students are effectively negligible when we analyze the average public high school, if we control for the average ability score at each school level.

${ }^{6}$ In other words, our estimation strategy is a regression difference-in-difference-in-difference estimation design.
} 
who received vouchers by randomized lotteries, on students' grades and on their likelihood of graduating and advancing to college.

Since our tuition support program, SRPHST, does not have an experimental design, it is certainly possible that prefectural governments changed their policies endogenously, and that each prefecture's policy variable is correlated with the local economic situation and dropout rate. Moreover, private high school students under generous SRPHST policies may be different from students under less generous policies in unobservable ways. Given our nonexperimental data, we address the possible endogeneity of local SRPHST programs by using an instrumental variable method and the possible selection of students at enrollment by controlling for the students' average ability. Our analysis identifies only the net effect of SRPHST programs on private school students, taking the local public school students as a baseline. ${ }^{7}$

There are at least two potential reasons why tuition support to private school students may affect the dropout behavior of recipient students: The first reason is the relaxation in the credit constraint for recipient families (Carneiro and Heckman 2002). The existence of credit constraint would make the continuation of schooling difficult for students from low-income families when they face economic difficulties. The second reason is an improvement in the match quality between students and schools (Abdulkadiroğlu and Sönmez 2003). By reducing tuition fees, SRPHST programs could create opportunities for improved matching and reduced overall dropout rates, when they allow students from low-income families to choose a private school that is more suited to a student's needs than is the local public school. Given the large share of public school enrollment, the change in average match quality at public schools due to student transfers is likely to be negligible, and the dropout rate at private schools will be reduced ${ }^{7}$ There was little change in the tuition reduction program for public school students during our data period. 
relative to the dropout rate at public schools.

\section{Data and Variables}

Our dependent variable — the average dropout rate at each high school—is calculated based on the enrollment of students by school-track-grade, which is obtained from High School Directory, published by Kyoritsu-Tsushin Co. ${ }^{8}$

This data set covers all high schools in eight prefectures in northern Japan (Aomori, Iwate, Akita, Miyagi, Yamagata,

Fukushima, Niigata, and Toyama) for a period of maximum 17 years. We created a sample of nearly all full-time

public and private high schools in the area, with near-complete records of the number of enrolled students in each

high school by grade, track, and year. We divided the scope of tracks into two categories: academic and vocational. ${ }^{9}$

Table 1 presents the number of tracks and mean dropout rates of $1^{\text {st }}$ and $2^{\text {nd }}$ grade students in each prefecture and year in the data set. The mean dropout rates in private high schools are generally higher than those in public high schools, which is consistent with official national statistics.

Our primary dependent variable is the annual "gross" dropout rate calculated by each school-track-grade. We define the annual gross dropout rate of $1^{\text {st }}$ and $2^{\text {nd }}$ grade students as follows:

Annual gross dropout rate of $1^{\text {st }}$ and $2^{\text {nd }}$ grade students

$$
=1-\left(\mathrm{n}_{\mathrm{t}+1,3}+\mathrm{n}_{\mathrm{t}+1,2}\right) /\left(\mathrm{n}_{\mathrm{t}, 2}+\mathrm{n}_{\mathrm{t}, 1}\right) \text {, }
$$

\footnotetext{
${ }^{8}$ When we found clear inconsistencies or errors in the enrollment, we supplemented the data with information from the Koto Gakko Soran published by Recruit Co.

${ }^{9}$ There is no national high school in our sample area. Our sample excludes part-time, correspondence, or specialized vocational high schools (called kousen). Our "academic" sample includes all tracks that primarily provide academic education for college, while our "“vocational" sample includes all other tracks, such as those for agriculture and engineering.
} 
where $\mathrm{n}_{\mathrm{t}, \mathrm{j}}$ represents the enrollment of $\mathrm{j}^{\text {th }}$ grade students in year $t$, with school and track indices suppressed. ${ }^{10}$ We call this variable the "two-grade pooled (or just pooled) dropout rate." We also estimate the programs' effect by using the annual dropout rates of the $j^{\text {st }}$ grade students $(j=1$ or 2 ) as a dependent variable. We call this variable the "single-grade dropout rate." Compared with the single-grade dropout rate, the pooled dropout rate is superior because it can reduce bias in measurement by internalizing those students who repeat grade 2. According to government statistics (MEXT 2008), the national average repetition rate in 2008 was $0.6 \%$ for the $1^{\text {st }}$ grade students in academic tracks, $0.3 \%$ for the $2^{\text {nd }}$ grade students in academic tracks, $0.7 \%$ for the $1^{\text {st }}$ grade students in vocational tracks, and $0.4 \%$ for the $2^{\text {nd }}$ grade students in vocational tracks. Overall, the repetition rate was approximately equivalent to $20 \%$ of the dropout rate in each course. To minimize the bias due to contamination from grade repetition, we mainly use the pooled dropout rate as a dependent variable. ${ }^{11}$

Figure 2 plots the pooled dropout rate by sector (public or private) and the unemployment rate in the Tohoku area between 1989 and 2005. The figure shows that through this period, high school dropout rates are positively correlated with unemployment rates in the area. ${ }^{12}$ The correlation coefficient between the dropout and unemployment rates is 0.33 for public high schools and 0.27 for private high schools. Since public school tuition waiver policy has remained mostly unchanged over this period, this positive correlation is consistent with the causal effect of economic conditions on dropout rates. Note, however, that there is a potential for a two-way causality between economic conditions and dropout rates for private school students through the endogenous changes of SRPHST programs by

\footnotetext{
${ }^{10}$ If a calculated dropout rate is negative (as $2.3 \%$ of all were), it is replaced by zero.

${ }^{11}$ The estimation result using the single-grade dropout rate as a dependent variable gives nearly identical estimates for all the parameters to those in Table 3-4. Thus, in our estimation, the bias due to the grade repetition can be safely considered negligible.

${ }^{12}$ Specifically, the level of dropout rates peaked in 2000 , followed by unemployment rates several years later.
} 
local governments.

-Figure 2-

Our policy variable, the average SRPHST grant per student, is calculated based on the data from The Annual Current State of Private School Subsidies (Japan Private High School Federation 1989-2006). Table 2 presents the amount of the average SRPHST grants in the sample prefectures under the two alternative definitions that we describe in detail below. ${ }^{13}$ It can be observed that during this period there were drastic changes in the amount of grants in some prefectures. These changes provide us with sources of identification of the tuition support policy effects.

We use two alternative measures of the generosity of SRPHST programs. The first is the average amount of grants per recipient student, calculated by dividing the actual total amount of tuition support grants by the actual total number of recipients. The second measure is the expected amount of grants per private student, calculated by dividing the actual total amount of grants by the total number of private high school students in each prefecture, obtained from the School Basic Survey (MEXT 2009). The first measure represents an intensive margin of the policy (an increase in the amount of grants for recipients), and the second measure is the sum of both intensive and extensive margins of the policy (such as relaxing the eligibility requirements for grants). Therefore, if potential students at private high schools can clearly predict their eligibility before enrollment, the first measure is more useful as a policy variable that can influence the enrollment decision. Meanwhile, if parents cannot clearly anticipate that they will be eligible for the

\footnotetext{
${ }^{13}$ There are other types of grants to private high school students that honor especially talented students in arts and sports. Our analysis excludes these types of grants.
} 
program, the second measure seems to be more relevant.

The second measure — the expected amount of grants per private student—can be problematic if it is correlated with local economic conditions. Welfare recipients are eligible to receive the maximum grant in most prefectures. Therefore, the total and expected amount of grants can be higher in economically distressed prefectures. We eliminate this confounding effect by controlling for the number of welfare recipients per 100,000 people in each prefecture, based on annual reports of Social Welfare Administration.

As previously noted, realized dropout rates may influence local SRPHST policy decisions. For instance, if there is an increasing number of dropouts in a prefecture, the prefectural government may relax the eligibility or increase the amount of grants. This reverse causality would presumably lead to an underestimation of the grants' preventative effect on dropouts. To address this problem, we use the ratio of the subsidy amount for private kindergartens to the subsidy amount for public kindergartens at prefectural level as an instrument for measures of the endogenous SRPHST amount. The SRPHST amount and the above instrument are positively correlated with each other, perhaps because they both reflect the generosity of prefectural governments toward private institutions. On the other hand, current private kindergarten policies are unlikely to affect the current dropout behavior of private high school students once we control for observed characteristics, and therefore they are clearly excluded from the equation for high school enrollment decision. As a source of data on the amount of private kindergarten subsidy, we use the statistics obtained from the National Association of Private Kindergartens and the data on the amount of public kindergarten subsidies from the Local Education Survey (MEXT, published annually).

In addition, it is likely that the initial academic ability of private high school students changes as local SRPHST 
policy changes, because of the self-selection of entering students. In order to account for this, we use the expected standardized test score on the entrance exam of each high school (called hensachi in Japan) as a measure of students' academic ability upon entering the school. The hensachi score is based on the average standardized test score of high school students admitted to each school. It is widely published every year and is regarded as a reliable measure of academic level of first-year high school students. Our data on the annual hensachi score by school track are obtained from the Annual Report of Hensachi of Japanese High Schools published by Kanjuku. The hensachi data for our eight prefectures cover nearly all high schools, except for those in Aomori prefecture. ${ }^{14}$ In the following analysis, we use the sample of high schools for which we have complete records of the hensachi score.

\section{Model}

We assume that the following model establishes the causal relationship between the dropout rate of high school students, $Y$, and the amount of SRPHST grants, $T$.

$$
Y_{k i j t}=\alpha+\delta T_{k t} D_{k i}+\beta D_{k i}+\phi A_{k i j t}+\gamma_{j}+\mu_{k t}+v_{k i}+\varepsilon_{k i j t}
$$

Here, $Y_{k i j t}$ is the yearly dropout rate of high school students in grade $j$ of school-track $i$ in prefecture $k$ in year $t . T_{k t}$ is the average per-student amount of SRPHST grants for private high school students in prefecture $k$ in year $t . D_{k i}$ is a dummy that takes 1 if high school track $i$ in prefecture $k$ is a private school. ${ }^{15}$ Since we expect that SRPHST grants affect only private school students, we include the interaction term between $D_{k i}$ and $T k t$. To control for the heterogeneity of students, schools, regions, and years, we include the average hensachi score of grade $j$ students in

\footnotetext{
${ }^{14}$ We performed an analysis excluding the Aomori sample completely; however, there was no difference in the signs and significance levels in the estimation results.

${ }^{15} D_{k i}$ is dropped when $v_{k i}$ is fully controlled.
} 
school track $i$ at year $t(A k i j t)$, an unobservable grade-group effect $\left(\gamma_{j}\right)$, an unobservable area and year group effect $\left(\mu_{k t}\right)$,

and an unobservable school-track effect $\left(v_{k i}\right) . \varepsilon_{k j t}$ is the error term, which may be correlated within regions and over years. $T k t$ is not included linearly, since it is constant within the same prefecture and year. The grade-group effect is controlled for only when the single-grade dropout rate is estimated.

Coefficient $\delta$ is expected to capture the difference in the effect of SRPHST grants on the dropout rate between private high schools and public high schools when the unobserved heterogeneity is fully controlled. As discussed in section $2.1, \delta$ is expected to be negative.

As mentioned earlier, the grant amount, $T_{k t}$, may be endogenously determined in response to a change in the dropout rate, $Y_{k i j t}$. To address this issue, we employ an instrumental variable estimation using $K_{k t}$, the ratio of subsidy amounts for private kindergartens to those for public kindergartens by prefecture and year as an instrument for $T_{k t}$. It is found that $K_{k t}$ is strongly correlated with $T_{k t}\left(1^{\text {st }}\right.$ stage).

Two issues should be noted regarding the distribution of the error term $\varepsilon$ : First, $\varepsilon_{\mathrm{kijt}}$ is likely to be correlated across years because of the existence of unobserved grade repetition. To reduce this bias, we primarily focus on the estimation of the pooled dropout rate, which tends to eliminate the grade repetition bias. Second, we test our hypotheses based on the cluster-robust standard errors, using prefectures as a unit of clustering. Allowing clustering of error terms within a prefecture solves not only the unobserved correlation over years but also possible unobserved correlation within schools or areas. Since the unit of our estimation is a school-track-grade cell, the behavior of students within the same school or the same area may be correlated with each other for reasons such as peer effect. By ignoring the correlation between tracks in the group, we may underestimate the standard errors (Moulton 1986, 
Angrist and Pischke 2009).

Finally, we discuss the estimation of non-negative dropout rates. It is traditional to employ a Tobit method if dropout rates are artificially censored and non-negative. However, the dropout rate is non-negative by definition, and there is no natural behavioral model allowing negative dropout rates. The linear probability model is sufficient in terms of consistent estimation of the policy parameter under censoring (Angrist and Pischke 2009), whereas a fixed-effect or a random-effect Tobit model would need to rely on strong assumptions. Therefore, we primarily employ the linear model. ${ }^{16}$

\section{Empirical Results}

\subsection{Estimation Results}

Table 3 reports the results on the effect of SRPHST programs on the two-grade pooled dropout rate by using the average amount of grants per recipient student as a measure of generosity of SRPHST grants. The sample is weighted by the enrollment of $1^{\text {st }}$ and $2^{\text {nd }}$ grade students at each school.

Columns (1)-(4) show the results of estimations in which the policy changes are considered exogenous. Columns (1) and (2) report simple ordinary least squares (OLS) estimates; columns (3) and (4) report fixed-effect estimates, controlling for unobservable school-track effect. We also add a prefecture dummy and a year dummy to Column (1), and a full set of prefecture-year dummies to Column (2), in order to account for unobservable regional

\footnotetext{
${ }^{16}$ For robustness, we estimated the model using a random-effect Tobit method. The results did not depart from the results using the linear model.
} 
and yearly fixed effects. ${ }^{17}$

As Columns (1)-(4) of Table 3 indicate, the coefficients on SRPHST grants variable, "SRPHST", and their interaction with the private high school dummy variable are not statistically significant when SRPHST is treated as exogenous. We, thus, cannot observe SRPHST grants' preventative effect on the dropout rate in either private or public high schools. In addition, in Columns (1) and (2), we can confirm that the dropout rate in private high school vocational tracks is higher than that in others, which is consistent with the trend shown in government statistics. The coefficient on Hensachi Score, a measure of students' ability at initial enrollment, is significantly negative at the $1 \%$ level in the OLS (Columns (1) and (2)). In other words, students with higher ability are less likely to drop out. The effect size of hensachi is large: one standard deviation increase in Hensachi Score is estimated to reduce the dropout rate by 1.5\%. Meanwhile, the coefficient on Hensachi Score reported in Columns (3) and (4) (fixed-effect estimates) is insignificant and small as compared with OLS estimates. It appears that part of the effect size of Hensachi Score in the OLS estimates is attributed to unobserved school characteristics; however, it is also possible that measurement errors in yearly changes in Hensachi Score, which do not change much each year, might generate an attenuation bias in the fixed effect estimates of the hensachi effects.

Columns (5)-(8) of Table 3 show the IV (two-stage least squares: 2SLS) estimates, which control for potential endogeneity of policy changes in SRPHST grants, using the ratio of subsidies for private kindergartens to subsidies for public kindergartens at prefecture level as an instrumental variable (Table 3 shows only the results of the second stage regression). ${ }^{18}$ Columns (5) and (6) are the pooled IV estimates, and, as in Columns (3) and (4), Columns (7) and

\footnotetext{
${ }^{17}$ Prefecture dummy is dropped in Columns (3) and (4) when track fixed effects are fully controlled.

${ }^{18}$ As for the $1^{\text {st }}$ stage regressions for Table 3 and Table 4, we confirm that our instrument variable is always positively correlated with the amounts of SRPHST grants significantly at $5 \%$ level. For more detailed results, contact the
} 
(8) are the fixed effect estimates that control for unobserved school-track effect. The dependent variable and other control variables are the same as in Columns (1)-(4).

The coefficients on Hensachi Score based on the IV estimation do not differ dramatically from the OLS estimates. Columns (5) and (6) are similar to Columns (1) and (2), and are significantly negative at the $1 \%$ level. However, when we control for unobserved school-track effect, the coefficient estimates become statistically insignificant and their sizes become smaller than those using the OLS.

The estimated coefficients on SRPHST in the pooled IV estimation results presented in Columns (5) and (6) are similar to the coefficients in the pooled OLS results in Columns (1) and (2). The coefficients on SRPHST and its interaction term with the private school dummy variable are not statistically significant. On the other hand, the fixed effect estimation results in Columns (7) and (8) show that coefficients on SRPHST x Private $x$ Vocational are significantly negative and larger than the positive coefficients on SRPHST x Private. These results suggest that an increase in the grant amounts reduces dropout rates of students in private vocational-track schools. Overall, the IV estimations generate significant policy effects with the expected signs while the OLS estimations do not generate any significant policy effects. These results suggest that there is potentially a reverse causality from high dropout rates to an increase in the amounts of grants (an expansion of grants), especially, in private vocational-track schools.

Finally, Table 4 reports the estimation results that use the expected amount of grants per private student as a measure of the amount of SRPHST grants. The dependent variable, estimation methods, and other explanatory variables all follow Table 3. Columns (1) and (2) report the OLS estimates and Columns (3) and (4) report the fixed effect estimates that control for unobservable school-track effects. corresponding author. 
The OLS estimates of the coefficients on SRPHST $\mathrm{x}$ Private $\mathrm{x}$ Vocational in Table 4 are negative and, unlike Table 3, statistically significant. The statistical significance disappears, however, once we control for school-track fixed effects in Columns (3) and (4). On the other hand, the result in Column (3) shows that an increase in the expected value of the grants significantly raises dropout rates in public high schools. Given the small share of private school students in the area, the generosity of SRPHST grants is unlikely to change the average characteristics of students and should not affect the dropout rates at public high schools. It is more likely that local policy regarding the expansion of SRPHST grants at the extensive margin is endogenous and influenced by an increase in the dropout rate of both public and private high school students. This is because an expansion of the extensive margin of the subsidy would have a greater positive impact on the expected amount of grants than on the average amount of grants.

The IV estimation results using the ratio of subsidies for private and public kindergartens as an IV, are presented in Columns (5)-(8) of Table 4. The main results are similar to the results of Table 3; namely, in Columns (5) and (6), without school-track fixed effects, we are not able to find a significant effect of SRPHST grants on dropout rates in private and public high schools. Once we control for the fixed effects in Columns (7) and (8), the coefficients on SRPHST $\mathrm{x}$ Private $\mathrm{x}$ Vocational are significantly negative, and the magnitude of their estimates is generally larger than that of the coefficient estimates on SRPHST x Private, which are insignificant. We can therefore conclude that an increase in the expected amount of grant per private student will significantly reduce dropout rates of vocational track students in private high schools. It is also observed that a positive significant effect of grants on dropout rates at public high schools does not survive in the IV estimation (Column (7)). Therefore, the positive effect of the grants on 
dropout rates at public schools obtained in Column (3) is likely to be driven by the reverse causality. All other parameter estimates are similar to those in Column (5)-(8) of Table 3. Coefficients on Hensachi Score are significantly negative in the OLS estimates, but become insignificant in the fixed effect model.

Our empirical findings are summarized as follows. First, using simple OLS, we are not able to obtain evidence that expanding SRPHST grants prevents students from dropping out of high school. Second, by using IV (2SLS) estimations that control for the endogeneity of local policy decisions regarding the grant, we find that both intensive and extensive expansion of SRPHST programs consistently reduces dropout rates of vocational-track students in private high schools. Our interpretation of the two contrasting results is that the IV estimates give us the true causal effect of SRPHST programs on high school dropout while the OLS estimates are contaminated by the reverse causality.

\subsection{Simple Cost-Benefit Analysis}

How large is the policy effect estimated in the regression analysis relative to its costs? It is difficult to answer this question precisely without any individual longitudinal data. In this subsection, we provide only a back-of-the-envelope cost-benefits analysis, applying the national average wage rates by educational achievement and ages in the public domain to our estimation results. The parameter estimate we focus on is the negative effect of SRPHST grants on dropout rates obtained in Column 8 of Table 3, which is $4.03 \%$.

More specifically, we use the 2005 Wage Census publication and construct the expected life-time wages of full-time workers for men and women of various educational backgrounds. Our analysis is limited by several factors: 
(1) we assume that all the graduates of high schools and junior high schools work on a full-time basis; (2) wage data are national averages, not averages from the eight prefectures used in this study; (3) we ignore the possibility that some high school dropouts successfully complete the high school diploma equivalent exam; and (4) our estimations do not distinguish between men and women, while wage data are available by sex.

Taking these limitations into account, we calculate the internal rate of return (IRR) to the SRPHST policy for private vocational-track students. The IRRs are found to be $8.53 \%$ for men and $14.20 \%$ for women. Although these are extremely rough calculations, the values obtained suggest that SRPHST grants are likely to have a reasonably high rate of return. This would seem to justify the grants as an effective measure for reducing dropout rates at private vocational high schools.

\section{Conclusion}

The main contribution of this study is to provide an econometric analysis of the effect of a tuition support program for private high school students from poor families—called SRPHST programs—-which has become a national education policy priority. We believe that this is the first empirical analysis of the effects of private school voucher programs in Japan, programs which are not widely known outside the country. Our estimation results show that an expansion of SRPHST programs significantly reduces dropout rates of students in vocational tracks of private high schools.

Why do such effects of the grants appear only among students in vocational tracks and not in general (academic) tracks? Although it is beyond the scope of this study to fully probe possible explanations for this finding, there are at least three possibilities. First, if the curriculum of vocational tracks is more substitutable for on-the-job training than 
the curriculum of academic tracks, the demand for vocational education is likely to be more elastic to the cost of high

school education than is the demand for academic education. Second, families of students who choose a vocational track might face more severe credit constraints than families of students who choose an academic track. ${ }^{19}$ The third explanation is that relaxing the budget (resource) constraint improves the match quality between students and school-tracks more for vocationally oriented students than for academically oriented students. ${ }^{20}$ To sort out these alternative explanations, more detailed data about family backgrounds of students and school characteristics are necessary.

Finally, to improve upon our back-on-the-envelope cost-benefits analysis, we at least need national representative individual panel data with wage records, so that we are able to estimate the effects of SRPHST program more precisely with fewer assumptions. These issues are left for future research.

\section{References}

Abdulkadiroğlu, A., Sönmez, T., 2003. School Choice: A Mechanism Design Approach. American Economic Review 93(3), 729-747.

Abdulkadiroğlu, A., Pathak, P.A., Roth, A.E., 2009. Strategy-proofness versus Efficiency in Matching with Indifferences: Redesigning the NYC High School Match. American Economic Review 99(5), 1954-1978.

Akabayashi, H., 2009. Average Effects of School Choice on Educational Attainment: Evidence from Japanese High School Attendance Zones. under review.

Angrist, J., Bettinger, E., Kremer, M., 2006. Long-Term Consequences of Secondary School Vouchers: Evidence from Administrative Records in Colombia. American Economic Review 96(3), 847-862.

Angrist, J., Pischke, J.-S., 2009. Mostly Harmless Econometrics: An Empiricist's Companion. Princeton: Princeton University Press.

19 The literature is divided on whether poorer families are more credit-constrained than richer families, theoretically and empirically. See Carneiro and Heckman (2002), Cunha et.al (2006), for details. ${ }^{20}$ Research of school choice in public school systems from the perspectives of matching has advanced in recent years (Abdulkadiroğlu and Sönmez 2003, Abdulkadiroğlu, Pathak, and Roth 2009). However, assignment mechanism of students to high schools that include private sector has not been well studied. 
Bettinger, E.P., 2005. The Effect of Charter Schools on Charter Students and Public Schools. Economics of Education Review 24(2),133-147.

Carneiro, P., Heckman, J.J., 2002. The Evidence on Credit Constraints in Post-Secondary Schooling. Economic Journal 112(482), 705-734.

Cullen, J. B., Jacob, B.A., Levitt, S., 2006. The Effect of School Choice on Participants: Evidence from Randomized Lotteries. Econometrica. 74(5), 1191-1230.

Cunha, F., Heckman, J.J., Lochner, L., Masterov, D.V., 2006. Interpreting the Evidence on Life Cycle Skill Formation. Hanushek, Welch, (Eds.) Handbook of Economics of Education Vol.I. Amsterdam: North-Holland, 697-812.

Hoxby, C. M., 2000. Does Competition Among Public Schools Benefit Students and Taxpayers? American Economic Review 90(5), 1209-1238.

Hsieh, C.-T., Urquiola, M., 2003. When Schools Compete, How do They Compete? An Assessment of Chile's Nationwide School Voucher Program. NBER Working Paper 10008.

Japan Private High School Federation, 2002. The Annual Current State of Private School Subsidies. (in Japanese)

MEXT (Ministry of Education, Culture, Sports, Science and Technology), 2008. The Current State of Issues on Student Guidance. Tokyo: MEXT.

MEXT (Ministry of Education, Culture, Sports, Science and Technology). 2009. School Basic Survey. Tokyo: MEXT.

MEXT (Ministry of Education, Culture, Sports, Science and Technology). Each year. Local Education Survey. Tokyo: MEXT.

Moulton, B., 1986. Random Group Effects and the Precision of Regression Estimates. Journal of Econometrics 32, 385-397.

Rouse, C.E., 1998. Private School Vouchers and Student Achievement: An Evaluation of the Milwaukee Parental Choice Program. Quarterly Journal of Economics 113(2), 553-602.

Sandstrom, F.M., Bergstrom, F., 2005. School Vouchers in Practice: Competition Will Not Hurt You. Journal of Public Economics 89, 351-380. 
Figure 1. Trends in the number of high school dropouts and dropout rates in Japan.

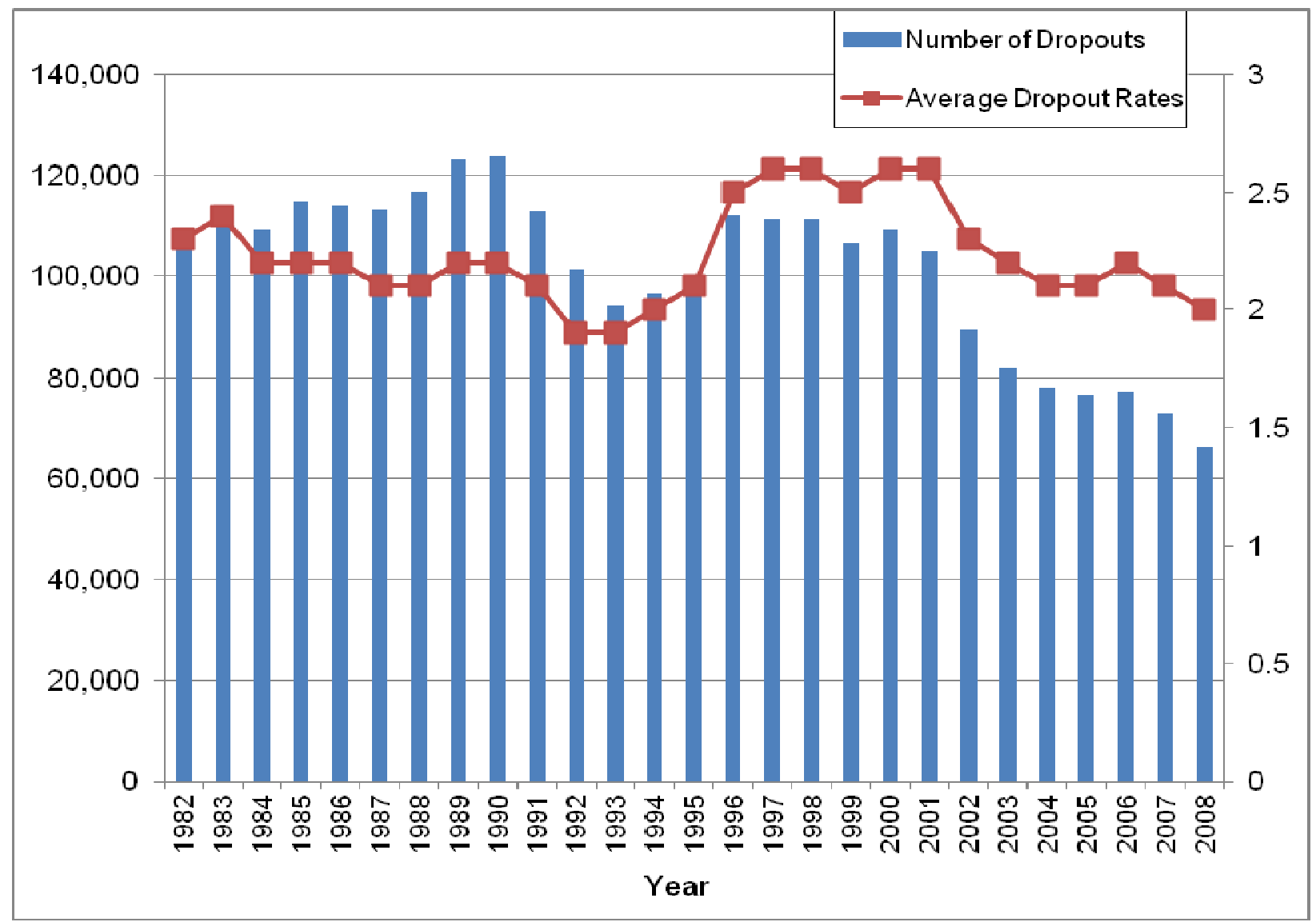

\begin{tabular}{|c|c|c|c|c|c|c|c|c|c|c|c|c|c|c|}
\hline Year & 1982 & 1983 & 1984 & 1985 & 1986 & 1987 & 1988 & 1989 & 1990 & 1991 & 1992 & 1993 & 1994 & 1995 \\
\hline $\begin{array}{l}\text { the Number of } \\
\text { Dropouts }\end{array}$ & 106,041 & 111,531 & 109,160 & 114,834 & 113,938 & 113,357 & 116,617 & 123,069 & 123,529 & 112,933 & 101,194 & 94,065 & 96,401 & 98,179 \\
\hline National & - & - & - & - & - & - & - & - & - & - & - & - & - & - \\
\hline Public & 65,314 & 67,932 & 67,009 & 72,086 & 73,176 & 73,127 & 75,791 & 81,332 & 82,846 & 76,684 & 68,822 & 63,428 & 64,229 & 64,431 \\
\hline Private & 40,727 & 43,599 & 42,151 & 42,748 & 40,762 & 40,230 & 40,826 & 41,737 & 40,683 & 36,249 & 32,372 & 30,637 & 32,172 & 33,748 \\
\hline $\begin{array}{l}\text { the Average } \\
\text { Dropout Rates }\end{array}$ & 2.3 & 2.4 & 2.2 & 2.2 & 2.2 & 2.1 & 2.1 & 2.2 & 2.2 & 2.1 & 1.9 & 1.9 & 2.0 & 2.1 \\
\hline National & - & - & - & - & - & - & - & - & - & - & - & - & - & - \\
\hline Public & 2.0 & 2.0 & 1.9 & 1.9 & 1.9 & 1.9 & 1.9 & 2.0 & 2.1 & 2.0 & 1.9 & 1.8 & 1.9 & 2.0 \\
\hline Private & 3.2 & 3.3 & 3.1 & 2.9 & 2.8 & 2.7 & 2.6 & 2.6 & 2.5 & 2.3 & 2.1 & 2.1 & 2.2 & 2.4 \\
\hline
\end{tabular}

\begin{tabular}{|l|rrrrrrrrrrrrr}
\hline Year & 1996 & 1997 & 1998 & 1999 & 2000 & 2001 & 2002 & 2003 & 2004 & 2005 & 2006 & 2007 & 2008 \\
\hline $\begin{array}{l}\text { the Number of } \\
\text { Dropouts }\end{array}$ & 112,150 & 111,491 & 111,372 & 106,578 & 109,146 & 104,894 & 89,409 & 81,799 & 77,897 & 76,693 & 77,027 & 72,854 & 66,226 \\
\hline National & - & - & - & - & - & - & - & - & - & 53 & 44 & 45 & 52 \\
Public & 73,736 & 73,654 & 73,474 & 70,554 & 73,253 & 70,528 & 60,633 & 55,668 & 53,261 & 53,117 & 53,251 & 50,529 & 45,742 \\
Private & 38,414 & 37,837 & 37,898 & 36,024 & 35,893 & 34,366 & 28,776 & 26,131 & 24,636 & 23,523 & 23,732 & 22,280 & 20,432 \\
\hline the Average & 2.5 & 2.6 & 2.6 & 2.5 & 2.6 & 2.6 & 2.3 & 2.2 & 2.1 & 2.1 & 2.2 & 2.1 & 2.0 \\
Dropout Rates & - & - & - & - & - & - & - & - & - & 0.6 & 0.5 & 0.5 & 0.5 \\
National & 2.3 & 2.4 & 2.5 & 2.4 & 2.5 & 2.5 & 2.2 & 2.1 & 2.0 & 2.1 & 2.2 & 2.1 & 1.9 \\
Public & 2.8 & 2.9 & 3.0 & 2.9 & 2.9 & 2.9 & 2.5 & 2.4 & 2.3 & 2.2 & 2.3 & 2.2 \\
Private & & & & & & & & 2.3 \\
\hline
\end{tabular}

Source: MEXT (2005), adapted by the authors. 
Figure 2. Changes in the two-grade pooled dropout rates by sector (public or private) in the eight prefectures used in the analysis, and the unemployment rate in the Tohoku area.

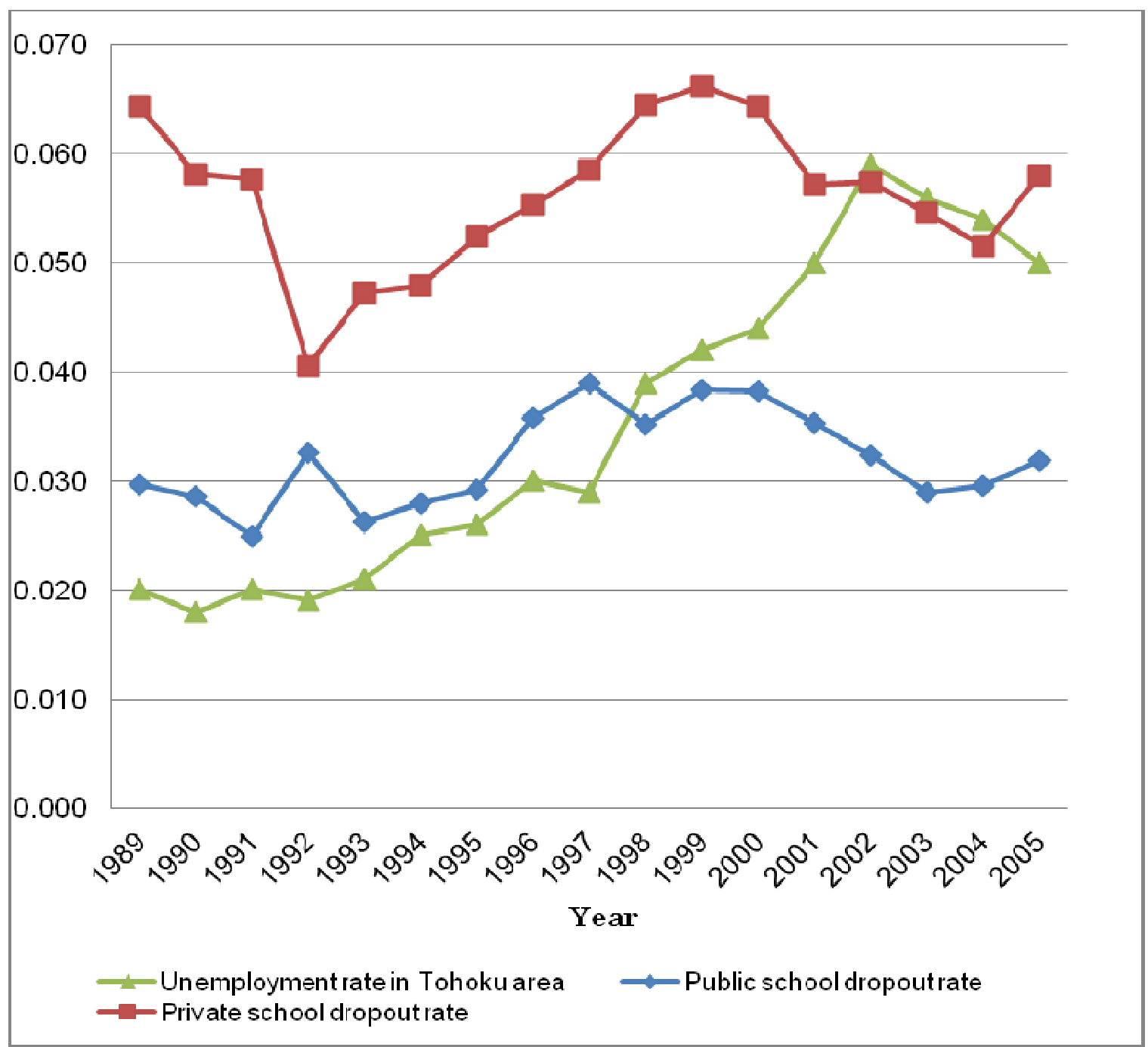

Source: High School Directory (Kyoritsu-Tsushin Co., published annually) and Labor Force Survey (Ministry of Internal Affairs and Communications, published annually), adapted by the authors. 
Table 1. Summary statistics for public high schools (panel A) and private high schools (panel B).

Panel A (public high schools)

\begin{tabular}{|c|c|c|c|c|c|c|c|c|}
\hline year & Aomori & Iwate & Miyagi & Akita & Yamagata & Fukushima & Niigata & Toyama \\
\hline 1990 & $\begin{array}{c}14 \\
0.01915\end{array}$ & $\begin{array}{c}178 \\
0.03223\end{array}$ & & $\begin{array}{c}97 \\
0.03063\end{array}$ & $\begin{array}{c}69 \\
0.01167\end{array}$ & & & \\
\hline 1991 & $\begin{array}{c}16 \\
0.03039\end{array}$ & & & & & & & \\
\hline 1992 & & & & & & $\begin{array}{c}168 \\
0.02974\end{array}$ & & \\
\hline 1993 & & $\begin{array}{c}196 \\
0.02727\end{array}$ & & & $\begin{array}{c}69 \\
0.01323\end{array}$ & $\begin{array}{c}167 \\
0.02711\end{array}$ & & \\
\hline 1994 & $\begin{array}{c}15 \\
0.02398\end{array}$ & $\begin{array}{c}197 \\
0.02529\end{array}$ & & & $\begin{array}{c}123 \\
0.02166\end{array}$ & $\begin{array}{c}183 \\
0.02660\end{array}$ & $\begin{array}{c}84 \\
0.04944\end{array}$ & \\
\hline 1995 & $\begin{array}{c}15 \\
0.01808\end{array}$ & $\begin{array}{c}198 \\
0.02588\end{array}$ & & $\begin{array}{c}116 \\
0.02288\end{array}$ & $\begin{array}{c}123 \\
0.02335\end{array}$ & $\begin{array}{c}187 \\
0.02644\end{array}$ & $\begin{array}{c}218 \\
0.04539\end{array}$ & \\
\hline 1996 & & $\begin{array}{c}200 \\
0.03091\end{array}$ & $\begin{array}{c}166 \\
0.04318\end{array}$ & $\begin{array}{c}112 \\
0.03239\end{array}$ & $\begin{array}{c}126 \\
0.02527\end{array}$ & $\begin{array}{c}195 \\
0.03100\end{array}$ & $\begin{array}{c}206 \\
0.05412\end{array}$ & \\
\hline 1997 & & $\begin{array}{c}174 \\
0.03523\end{array}$ & $\begin{array}{c}163 \\
0.04165\end{array}$ & $\begin{array}{c}111 \\
0.03253\end{array}$ & $\begin{array}{c}129 \\
0.03227\end{array}$ & $\begin{array}{c}202 \\
0.03207\end{array}$ & $\begin{array}{c}189 \\
0.07818\end{array}$ & $\begin{array}{c}112 \\
0.02776\end{array}$ \\
\hline 1998 & & $\begin{array}{c}166 \\
0.02969\end{array}$ & $\begin{array}{c}170 \\
0.03143\end{array}$ & $\begin{array}{c}125 \\
0.03123\end{array}$ & $\begin{array}{c}123 \\
0.02804\end{array}$ & $\begin{array}{c}204 \\
0.01948\end{array}$ & $\begin{array}{c}144 \\
0.06982\end{array}$ & $\begin{array}{c}107 \\
0.01938\end{array}$ \\
\hline 1999 & $\begin{array}{c}86 \\
0.02287\end{array}$ & $\begin{array}{c}162 \\
0.03863\end{array}$ & $\begin{array}{c}169 \\
0.03616\end{array}$ & $\begin{array}{c}120 \\
0.03081\end{array}$ & $\begin{array}{c}123 \\
0.03003\end{array}$ & $\begin{array}{c}3 \\
0.00000\end{array}$ & $\begin{array}{c}195 \\
0.06118\end{array}$ & $\begin{array}{c}108 \\
0.02786\end{array}$ \\
\hline 2000 & $\begin{array}{c}86 \\
0.02523\end{array}$ & $\begin{array}{c}182 \\
0.03887\end{array}$ & $\begin{array}{c}167 \\
0.03591\end{array}$ & $\begin{array}{c}115 \\
0.03498\end{array}$ & $\begin{array}{c}125 \\
0.02552\end{array}$ & $\begin{array}{c}183 \\
0.03281\end{array}$ & $\begin{array}{c}187 \\
0.05960\end{array}$ & $\begin{array}{c}109 \\
0.02712\end{array}$ \\
\hline 2001 & $\begin{array}{c}87 \\
0.01964\end{array}$ & $\begin{array}{c}190 \\
0.03684\end{array}$ & $\begin{array}{c}163 \\
0.03312\end{array}$ & $\begin{array}{c}121 \\
0.03031\end{array}$ & $\begin{array}{c}130 \\
0.02224\end{array}$ & $\begin{array}{c}189 \\
0.03406\end{array}$ & $\begin{array}{c}178 \\
0.05304\end{array}$ & $\begin{array}{c}106 \\
0.02447\end{array}$ \\
\hline 2002 & $\begin{array}{c}87 \\
0.01796\end{array}$ & $\begin{array}{c}191 \\
0.03312\end{array}$ & $\begin{array}{c}157 \\
0.03019\end{array}$ & $\begin{array}{c}118 \\
0.03081\end{array}$ & $\begin{array}{c}136 \\
0.02039\end{array}$ & $\begin{array}{c}186 \\
0.02964\end{array}$ & $\begin{array}{c}167 \\
0.05306\end{array}$ & $\begin{array}{c}99 \\
0.02465\end{array}$ \\
\hline 2003 & $\begin{array}{c}88 \\
0.01663\end{array}$ & $\begin{array}{c}192 \\
0.02853\end{array}$ & $\begin{array}{c}161 \\
0.02939\end{array}$ & $\begin{array}{c}113 \\
0.02945\end{array}$ & $\begin{array}{c}126 \\
0.02017\end{array}$ & $\begin{array}{c}186 \\
0.02944\end{array}$ & $\begin{array}{c}162 \\
0.04296\end{array}$ & $\begin{array}{c}97 \\
0.02077\end{array}$ \\
\hline 2004 & $\begin{array}{c}87 \\
0.01444\end{array}$ & $\begin{array}{c}183 \\
0.02793\end{array}$ & $\begin{array}{c}163 \\
0.03112\end{array}$ & $\begin{array}{c}115 \\
0.02590\end{array}$ & $\begin{array}{c}114 \\
0.01951\end{array}$ & $\begin{array}{c}183 \\
0.03107\end{array}$ & $\begin{array}{c}162 \\
0.04239\end{array}$ & $\begin{array}{c}95 \\
0.02268\end{array}$ \\
\hline
\end{tabular}


Panel B (Private high schools)

\begin{tabular}{|c|c|c|c|c|c|c|c|c|}
\hline year & Aomori & Iwate & Miyagi & Akita & Yamagata & Fukushima & Niigata & Toyama \\
\hline 1990 & $\begin{array}{c}1 \\
0.02619\end{array}$ & $\begin{array}{c}33 \\
0.06222\end{array}$ & & $\begin{array}{c}10 \\
0.02933\end{array}$ & $\begin{array}{c}11 \\
0.07771\end{array}$ & & & \\
\hline 1991 & $\begin{array}{c}1 \\
0.01098\end{array}$ & & & & & & & \\
\hline 1992 & & & & & & $\begin{array}{c}30 \\
0.03337\end{array}$ & & \\
\hline 1993 & & $\begin{array}{c}36 \\
0.05791\end{array}$ & & & $\begin{array}{c}12 \\
0.06501\end{array}$ & $\begin{array}{c}32 \\
0.03273\end{array}$ & & \\
\hline 1994 & $\begin{array}{c}1 \\
0.06530\end{array}$ & $\begin{array}{c}36 \\
0.03677\end{array}$ & & & $\begin{array}{c}9 \\
0.03730\end{array}$ & $\begin{array}{c}34 \\
0.04791\end{array}$ & $\begin{array}{c}6 \\
0.02812\end{array}$ & \\
\hline 1995 & $\begin{array}{c}1 \\
0.03619\end{array}$ & $\begin{array}{c}34 \\
0.05858\end{array}$ & & $\begin{array}{c}10 \\
0.04106\end{array}$ & $\begin{array}{c}9 \\
0.03774\end{array}$ & $\begin{array}{c}36 \\
0.04277\end{array}$ & $\begin{array}{c}21 \\
0.01829\end{array}$ & \\
\hline 1996 & & $\begin{array}{c}34 \\
0.06211\end{array}$ & $\begin{array}{c}32 \\
0.04675\end{array}$ & $\begin{array}{c}10 \\
0.05790\end{array}$ & $\begin{array}{c}9 \\
0.05307\end{array}$ & $\begin{array}{c}37 \\
0.04793\end{array}$ & $\begin{array}{c}20 \\
0.02468\end{array}$ & \\
\hline 1997 & & $\begin{array}{c}34 \\
0.06291\end{array}$ & $\begin{array}{c}32 \\
0.04736\end{array}$ & $\begin{array}{c}10 \\
0.05695\end{array}$ & $\begin{array}{c}9 \\
0.05113\end{array}$ & $\begin{array}{c}36 \\
0.04482\end{array}$ & $\begin{array}{c}18 \\
0.03080\end{array}$ & $\begin{array}{c}9 \\
0.07259\end{array}$ \\
\hline 1998 & & $\begin{array}{c}33 \\
0.06913\end{array}$ & $\begin{array}{c}31 \\
0.04931\end{array}$ & $\begin{array}{c}9 \\
0.06439\end{array}$ & $\begin{array}{c}27 \\
0.07327\end{array}$ & & $\begin{array}{c}21 \\
0.05113\end{array}$ & $\begin{array}{c}10 \\
0.07317\end{array}$ \\
\hline 1999 & $\begin{array}{c}33 \\
0.06439\end{array}$ & $\begin{array}{c}33 \\
0.06997\end{array}$ & $\begin{array}{c}33 \\
0.05239\end{array}$ & $\begin{array}{c}9 \\
0.06942\end{array}$ & $\begin{array}{c}28 \\
0.08181\end{array}$ & & $\begin{array}{c}22 \\
0.04574\end{array}$ & $\begin{array}{c}10 \\
0.08177\end{array}$ \\
\hline 2000 & $\begin{array}{c}33 \\
0.07034\end{array}$ & $\begin{array}{c}27 \\
0.07130\end{array}$ & $\begin{array}{c}33 \\
0.05701\end{array}$ & $\begin{array}{c}9 \\
0.07820\end{array}$ & $\begin{array}{c}30 \\
0.07535\end{array}$ & $\begin{array}{c}34 \\
0.04898\end{array}$ & $\begin{array}{c}22 \\
0.04033\end{array}$ & $\begin{array}{c}10 \\
0.08953\end{array}$ \\
\hline 2001 & $\begin{array}{c}33 \\
0.05635\end{array}$ & $\begin{array}{c}29 \\
0.06802\end{array}$ & $\begin{array}{c}33 \\
0.04790\end{array}$ & $\begin{array}{c}10 \\
0.06236\end{array}$ & $\begin{array}{c}34 \\
0.06018\end{array}$ & $\begin{array}{c}32 \\
0.04489\end{array}$ & $\begin{array}{c}21 \\
0.04202\end{array}$ & $\begin{array}{c}10 \\
0.08235\end{array}$ \\
\hline 2002 & $\begin{array}{c}36 \\
0.06914\end{array}$ & $\begin{array}{c}30 \\
0.05137\end{array}$ & $\begin{array}{c}32 \\
0.05436\end{array}$ & $\begin{array}{c}10 \\
0.05331\end{array}$ & $\begin{array}{c}35 \\
0.05249\end{array}$ & $\begin{array}{c}30 \\
0.05524\end{array}$ & $\begin{array}{c}21 \\
0.04105\end{array}$ & $\begin{array}{c}10 \\
0.08493\end{array}$ \\
\hline 2003 & $\begin{array}{c}37 \\
0.05891\end{array}$ & $\begin{array}{c}28 \\
0.06350\end{array}$ & $\begin{array}{c}34 \\
0.06159\end{array}$ & $\begin{array}{c}9 \\
0.04342\end{array}$ & $\begin{array}{c}35 \\
0.04760\end{array}$ & $\begin{array}{c}35 \\
0.03798\end{array}$ & $\begin{array}{c}20 \\
0.03694\end{array}$ & $\begin{array}{c}10 \\
0.06707\end{array}$ \\
\hline 2004 & $\begin{array}{c}35 \\
0.06274\end{array}$ & $\begin{array}{c}28 \\
0.04903\end{array}$ & $\begin{array}{c}37 \\
0.05469\end{array}$ & $\begin{array}{c}9 \\
0.02900\end{array}$ & $\begin{array}{c}35 \\
0.04909\end{array}$ & $\begin{array}{c}34 \\
0.05101\end{array}$ & $\begin{array}{c}20 \\
0.03799\end{array}$ & $\begin{array}{c}10 \\
0.04955\end{array}$ \\
\hline
\end{tabular}

Note: For both panels A and B, each row comprises three statistics: the number of tracks (top) and the average two-grade pooled dropout rates (bottom). Columns show the year and names of eight prefectures. 
Table 2. The amount of SRPHST grant per student in yen by two definitions: the average amount of grants per recipient student (top) and the expected amount of grants per private student (bottom).

\begin{tabular}{|c|c|c|c|c|c|c|c|c|}
\hline year & Aomori & Iwate & Miyagi & Akita & Yamagata & Fukushima & Niigata & Toyama \\
\hline 1988 & & & & $\begin{array}{r}67153.34 \\
1935.26\end{array}$ & & & & \\
\hline 1989 & $\begin{array}{r}35409.80 \\
2708.06\end{array}$ & $\begin{array}{r}73572.09 \\
3718.26\end{array}$ & & $\begin{array}{r}82581.65 \\
2429.78\end{array}$ & & & & \\
\hline 1990 & $\begin{array}{r}38974.45 \\
2634.16\end{array}$ & $\begin{array}{r}79056.42 \\
3802.66\end{array}$ & $\begin{array}{r}186707.30 \\
4715.41\end{array}$ & $\begin{array}{r}87365.71 \\
2755.27\end{array}$ & $\begin{array}{r}79648.74 \\
2878.31\end{array}$ & $\begin{array}{r}158502.80 \\
2414.44\end{array}$ & $\begin{array}{r}74631.04 \\
6396.00\end{array}$ & $\begin{array}{r}85752.28 \\
2873.80\end{array}$ \\
\hline 1991 & $\begin{array}{r}43189.80 \\
2548.89\end{array}$ & $\begin{array}{r}78860.45 \\
3564.81\end{array}$ & $\begin{array}{r}195551.30 \\
4660.04\end{array}$ & $\begin{array}{r}86662.65 \\
2516.80\end{array}$ & $\begin{array}{r}82106.09 \\
3119.33\end{array}$ & $\begin{array}{r}165451.90 \\
2729.36\end{array}$ & $\begin{array}{r}75675.42 \\
5737.49\end{array}$ & $\begin{array}{r}87713.92 \\
2864.81\end{array}$ \\
\hline 1992 & $\begin{array}{r}50272.19 \\
2682.44\end{array}$ & $\begin{array}{r}87371.39 \\
3508.35\end{array}$ & $\begin{array}{r}206529.20 \\
4525.52\end{array}$ & $\begin{array}{r}87936.66 \\
2672.40\end{array}$ & $\begin{array}{r}91418.99 \\
3314.34\end{array}$ & $\begin{array}{r}182652.30 \\
2887.43\end{array}$ & $\begin{array}{r}75635.94 \\
4525.77\end{array}$ & $\begin{array}{r}89910.14 \\
2837.39\end{array}$ \\
\hline 1993 & $\begin{array}{r}52463.43 \\
2523.19\end{array}$ & $\begin{array}{r}88012.63 \\
3323.00\end{array}$ & $\begin{array}{r}215291.40 \\
5068.35\end{array}$ & $\begin{array}{r}96050.81 \\
2995.52\end{array}$ & $\begin{array}{r}93074.81 \\
3343.32\end{array}$ & $\begin{array}{r}190714.30 \\
3171.60\end{array}$ & $\begin{array}{r}91399.89 \\
9650.92\end{array}$ & $\begin{array}{r}95195.51 \\
3054.77\end{array}$ \\
\hline 1994 & $\begin{array}{r}52459.13 \\
2404.93\end{array}$ & $\begin{array}{r}96606.88 \\
3850.65\end{array}$ & $\begin{array}{r}232198.30 \\
5313.57\end{array}$ & $\begin{array}{r}97761.91 \\
2723.26\end{array}$ & $\begin{array}{r}91466.02 \\
3784.04\end{array}$ & $\begin{array}{r}203779.60 \\
3508.24\end{array}$ & $\begin{array}{l}94797.95 \\
10066.16\end{array}$ & $\begin{array}{r}97694.62 \\
3278.78\end{array}$ \\
\hline 1995 & $\begin{array}{r}52169.16 \\
2306.81\end{array}$ & $\begin{array}{r}102023.20 \\
3948.63\end{array}$ & $\begin{array}{r}238924.20 \\
5969.87\end{array}$ & $\begin{array}{r}96836.73 \\
2380.83\end{array}$ & $\begin{array}{r}102112.00 \\
4665.99\end{array}$ & $\begin{array}{r}212392.60 \\
3642.48\end{array}$ & $\begin{array}{r}93464.40 \\
9441.90\end{array}$ & $\begin{array}{r}100059.90 \\
3652.85\end{array}$ \\
\hline 1996 & $\begin{array}{r}60849.54 \\
2202.21\end{array}$ & $\begin{array}{r}102303.30 \\
3883.03\end{array}$ & $\begin{array}{r}232095.90 \\
7469.92\end{array}$ & $\begin{array}{r}143577.90 \\
3413.88\end{array}$ & $\begin{array}{r}98368.15 \\
4894.27\end{array}$ & $\begin{array}{r}222662.00 \\
3561.31\end{array}$ & $\begin{array}{r}107216.10 \\
11148.99\end{array}$ & $\begin{array}{r}118720.90 \\
4355.66\end{array}$ \\
\hline 1997 & $\begin{array}{r}103149.50 \\
4854.18\end{array}$ & $\begin{array}{r}102683.20 \\
4081.21\end{array}$ & $\begin{array}{r}232265.30 \\
8483.62\end{array}$ & $\begin{array}{r}142815.10 \\
3610.64\end{array}$ & $\begin{array}{r}98774.76 \\
5111.34\end{array}$ & $\begin{array}{r}231056.40 \\
3608.57\end{array}$ & $\begin{array}{r}107227.00 \\
10681.05\end{array}$ & $\begin{array}{r}137862.80 \\
4996.57\end{array}$ \\
\hline 1998 & $\begin{array}{r}98344.84 \\
5746.16\end{array}$ & $\begin{array}{r}106128.50 \\
4803.11\end{array}$ & $\begin{array}{r}246958.00 \\
11318.00\end{array}$ & $\begin{array}{r}135966.00 \\
3827.46\end{array}$ & $\begin{array}{r}100403.30 \\
6343.64\end{array}$ & $\begin{array}{r}231533.80 \\
3659.05\end{array}$ & $\begin{array}{r}115667.30 \\
12079.74\end{array}$ & $\begin{array}{r}143620.70 \\
5741.23\end{array}$ \\
\hline 1999 & $\begin{array}{r}104457.70 \\
6333.07\end{array}$ & $\begin{array}{r}105833.30 \\
5441.71\end{array}$ & $\begin{array}{r}233705.70 \\
11635.69\end{array}$ & $\begin{array}{r}133761.90 \\
3317.72\end{array}$ & $\begin{array}{r}96047.79 \\
6393.00\end{array}$ & $\begin{array}{r}230351.80 \\
4901.44\end{array}$ & $\begin{array}{r}113030.80 \\
15688.29\end{array}$ & $\begin{array}{r}150660.50 \\
6327.51\end{array}$ \\
\hline 2000 & $\begin{array}{r}105226.90 \\
6817.45\end{array}$ & $\begin{array}{r}108000.00 \\
5482.90\end{array}$ & $\begin{array}{r}217346.60 \\
11975.21\end{array}$ & $\begin{array}{r}123931.70 \\
3971.54\end{array}$ & $\begin{array}{r}96442.87 \\
6943.52\end{array}$ & $\begin{array}{r}236395.90 \\
5965.88\end{array}$ & $\begin{array}{r}113539.60 \\
17366.98\end{array}$ & $\begin{array}{r}149336.20 \\
6851.55\end{array}$ \\
\hline 2001 & $\begin{array}{r}106901.30 \\
7055.04\end{array}$ & $\begin{array}{r}109472.20 \\
6147.27\end{array}$ & $\begin{array}{r}220204.30 \\
13193.33\end{array}$ & $\begin{array}{r}124058.80 \\
5374.39\end{array}$ & $\begin{array}{r}97838.63 \\
7563.67\end{array}$ & $\begin{array}{r}234595.80 \\
7009.77\end{array}$ & $\begin{array}{r}114761.30 \\
18908.17\end{array}$ & $\begin{array}{r}149140.50 \\
7656.72\end{array}$ \\
\hline 2002 & $\begin{array}{r}103000.70 \\
7341.92\end{array}$ & $\begin{array}{r}109717.20 \\
6562.90\end{array}$ & $\begin{array}{r}220134.50 \\
15129.41\end{array}$ & $\begin{array}{r}123970.70 \\
6769.25\end{array}$ & $\begin{array}{r}96743.41 \\
8249.06\end{array}$ & $\begin{array}{r}246006.30 \\
8367.08\end{array}$ & $\begin{array}{r}118565.60 \\
21535.83\end{array}$ & $\begin{array}{r}146762.60 \\
8879.86\end{array}$ \\
\hline 2003 & $\begin{array}{r}104459.40 \\
9045.72\end{array}$ & $\begin{array}{r}104917.60 \\
7532.68\end{array}$ & $\begin{array}{r}221909.50 \\
18459.26\end{array}$ & $\begin{array}{r}125610.00 \\
7940.69\end{array}$ & $\begin{array}{r}98506.26 \\
9493.97\end{array}$ & $\begin{array}{r}245483.80 \\
10795.97\end{array}$ & $\begin{array}{r}122818.10 \\
24495.94\end{array}$ & $\begin{array}{r}153000.00 \\
9664.63\end{array}$ \\
\hline 2004 & $\begin{array}{r}106500.00 \\
9836.91\end{array}$ & $\begin{array}{r}112955.50 \\
9232.97\end{array}$ & $\begin{array}{r}219333.00 \\
20206.23\end{array}$ & $\begin{array}{r}150164.50 \\
11542.35\end{array}$ & $\begin{array}{r}98038.70 \\
9481.16\end{array}$ & $\begin{array}{r}250342.10 \\
13126.19\end{array}$ & $\begin{array}{r}124444.00 \\
28495.69\end{array}$ & $\begin{array}{r}176680.50 \\
13199.01\end{array}$ \\
\hline 2005 & $\begin{array}{r}111311.80 \\
11221.08\end{array}$ & $\begin{array}{r}112855.70 \\
9447.23\end{array}$ & $\begin{array}{r}225808.70 \\
22441.08\end{array}$ & $\begin{array}{r}152437.10 \\
13135.71\end{array}$ & $\begin{array}{r}97089.03 \\
9558.48\end{array}$ & $\begin{array}{r}248180.00 \\
15899.16\end{array}$ & $\begin{array}{r}128293.00 \\
30981.10\end{array}$ & $\begin{array}{r}174320.10 \\
14106.02\end{array}$ \\
\hline
\end{tabular}

Source: The Annual Current State of Private School Subsidy (Japan Private High School Federation, published annually), adapted by the authors. 
Table 3. The estimation results of the effect of the SRPHST grant on the dropout rate. The SRPHST variable is the average grant amount per recipient student.

\begin{tabular}{|c|c|c|c|c|c|c|c|c|}
\hline & $(1)$ & $(2)$ & (3) & $(4)$ & (5) & (6) & (7) & (8) \\
\hline & OLS & OLS & FE & FE & 2SLS & $2 S L S$ & 2SLS/FE & 2SLS/FE \\
\hline Hensachi Score & $\begin{array}{l}-0.209 \\
(0.019)^{\star \star}\end{array}$ & $\begin{array}{c}-0.212 \\
(0.020)^{\star \star}\end{array}$ & $\begin{array}{c}-0.032 \\
(0.013)^{\star}\end{array}$ & $\begin{array}{l}-0.022 \\
(0.017)\end{array}$ & $\begin{array}{l}-0.206 \\
(0.015)^{\star \star}\end{array}$ & $\begin{array}{l}-0.208 \\
(0.015)^{\star \star}\end{array}$ & $\begin{array}{c}0.001 \\
(0.021)\end{array}$ & $\begin{array}{l}0.006 \\
(0.022)\end{array}$ \\
\hline SRPHST & $\begin{array}{l}-0.020 \\
(0.040)\end{array}$ & & $\begin{array}{c}0.002 \\
(0.048)\end{array}$ & & $\begin{array}{c}0.016 \\
(0.088)\end{array}$ & & $\begin{array}{l}0.207 \\
(0.117)\end{array}$ & \\
\hline SRPHST $x$ Private & $\begin{array}{c}0.097 \\
(0.084)\end{array}$ & $\begin{array}{c}0.098 \\
(0.085)\end{array}$ & $\begin{array}{l}0.045 \\
(0.100)\end{array}$ & $\begin{array}{c}0.046 \\
(0.098)\end{array}$ & $\begin{array}{l}-0.003 \\
(0.108)\end{array}$ & $\begin{array}{l}-0.002 \\
(0.110)\end{array}$ & $\begin{array}{c}0.234 \\
(0.151)\end{array}$ & $\begin{array}{c}0.241 \\
(0.154)\end{array}$ \\
\hline $\begin{array}{l}\text { SRPHST } x \\
\text { Vocational }\end{array}$ & $\begin{array}{l}-0.010 \\
(0.034)\end{array}$ & $\begin{array}{l}-0.010 \\
(0.034)\end{array}$ & $\begin{array}{l}-0.066 \\
(0.062)\end{array}$ & $\begin{array}{l}-0.070 \\
(0.063)\end{array}$ & $\begin{array}{l}-0.074 \\
(0.036)\end{array}$ & $\begin{array}{l}-0.075 \\
(0.037)\end{array}$ & $\begin{array}{l}-0.097 \\
(0.115)\end{array}$ & $\begin{array}{l}-0.113 \\
(0.114)\end{array}$ \\
\hline $\begin{array}{c}\text { SRPHST } x \text { Private } x \\
\text { Vocational }\end{array}$ & $\begin{array}{l}-0.086 \\
(0.048)\end{array}$ & $\begin{array}{l}-0.086 \\
(0.048)\end{array}$ & $\begin{array}{l}-0.038 \\
(0.151)\end{array}$ & $\begin{array}{l}-0.040 \\
(0.151)\end{array}$ & $\begin{array}{c}0.021 \\
(0.111)\end{array}$ & $\begin{array}{c}0.023 \\
(0.112)\end{array}$ & $\begin{array}{c}-0.409 \\
(0.107)^{\star \star}\end{array}$ & $\begin{array}{l}-0.403 \\
(0.107)^{\star \star}\end{array}$ \\
\hline Private (dummy) & $\begin{array}{l}-0.006 \\
(0.017)\end{array}$ & $\begin{array}{l}-0.007 \\
(0.017)\end{array}$ & & & $\begin{array}{c}0.009 \\
(0.017)\end{array}$ & $\begin{array}{l}0.009 \\
(0.017)\end{array}$ & & \\
\hline $\begin{array}{l}\text { Vocational Track } \\
\text { (dummy) }\end{array}$ & $\begin{array}{l}-0.004 \\
(0.005)\end{array}$ & $\begin{array}{l}-0.004 \\
(0.005)\end{array}$ & & & $\begin{array}{c}0.007 \\
(0.006)\end{array}$ & $\begin{array}{c}0.007 \\
(0.006)\end{array}$ & & \\
\hline Private $x$ Vocational & $\begin{array}{c}0.025 \\
(0.007)^{\star \star}\end{array}$ & $\begin{array}{c}0.025 \\
(0.007)^{\star \star}\end{array}$ & & & $\begin{array}{c}0.009 \\
(0.020)\end{array}$ & $\begin{array}{c}0.009 \\
(0.020)\end{array}$ & & \\
\hline Year control & yes & yes & Yes & yes & yes & yes & yes & yes \\
\hline Prefecture control & yes & yes & & & yes & yes & & \\
\hline Year x Prefecture & & yes & & yes & & yes & & yes \\
\hline $\mathrm{N}$ & 13464 & 13464 & 13401 & 13401 & 13464 & 13464 & 13401 & 13401 \\
\hline $\mathrm{R}^{2}$ & 0.30 & 0.31 & 0.67 & 0.68 & 0.30 & 0.30 & 0.02 & 0.03 \\
\hline
\end{tabular}

Note: Dependent variable is the two-grade pooled dropout rates (\%). The measure of the SRPHST is the average amount of the grant per recipients in 1 million yen. Columns. (3), (4), (7), and (8) control for group fixed-effects for each track. All regressions are weighted by grade 1 and 2 enrollment for each year. Clustered-robust standard errors at prefecture level are shown in parentheses. Instruments used in Columns. (5) - (8) are the ratio of private kindergarten subsidies to public ones by prefecture and year. Significance level: **1\%. *5\%. 
Table 4. The estimation results of the effect of the SRPHST grant on the dropout rate. The SRPHST variable is the expected amount of grant per recipient student.

\begin{tabular}{|c|c|c|c|c|c|c|c|c|}
\hline & $(1)$ & $(2)$ & (3) & $(4)$ & (5) & (6) & $(7)$ & (8) \\
\hline & OLS & OLS & FE & FE & $2 S L S$ & $2 S L S$ & 2SLS/FE & 2SLS/FE \\
\hline Hensachi Score & $\begin{array}{l}-0.207 \\
(0.018)^{\star \star}\end{array}$ & $\begin{array}{l}-0.209 \\
(0.018)^{\star \star}\end{array}$ & $\begin{array}{l}-0.027 \\
(0.011)^{\star}\end{array}$ & $\begin{array}{l}-0.019 \\
(0.015)\end{array}$ & $\begin{array}{l}-0.205 \\
(0.017)^{\star \star}\end{array}$ & $\begin{array}{l}-0.207 \\
(0.017)^{\star \star}\end{array}$ & $\begin{array}{c}0.011 \\
(0.022)\end{array}$ & $\begin{array}{c}0.013 \\
(0.022)\end{array}$ \\
\hline $\begin{array}{l}\text { People on Welfare } \\
\text { per } 100,000\end{array}$ & $\begin{array}{c}0.030 \\
(0.050)\end{array}$ & & $\begin{array}{c}0.116 \\
(0.066)\end{array}$ & & $\begin{array}{c}0.010 \\
(0.045)\end{array}$ & & $\begin{array}{c}0.083 \\
(0.145)\end{array}$ & \\
\hline SRPHST & $\begin{array}{c}0.167 \\
(0.147)\end{array}$ & & $\begin{array}{c}0307 \\
(0.085)^{\star \star}\end{array}$ & & $\begin{array}{c}0332 \\
(0.471)\end{array}$ & & $\begin{array}{l}-0.743 \\
(0.521)\end{array}$ & \\
\hline SRPHST $x$ Private & $\begin{array}{l}-0.556 \\
(0.850)\end{array}$ & $\begin{array}{l}-0.559 \\
(0.860)\end{array}$ & $\begin{array}{c}0.405 \\
(0.315)\end{array}$ & $\begin{array}{c}0.409 \\
(0.327)\end{array}$ & $\begin{array}{l}-0.123 \\
(1.173)\end{array}$ & $\begin{array}{l}-0.118 \\
(1.188)\end{array}$ & $\begin{array}{l}1.140 \\
(0.828)\end{array}$ & $\begin{array}{c}1.132 \\
(0.816)\end{array}$ \\
\hline $\begin{array}{l}\text { SRPHST } x \\
\text { Vocational }\end{array}$ & $\begin{array}{c}0.143 \\
(0.138)\end{array}$ & $\begin{array}{c}0.136 \\
(0.141)\end{array}$ & $\begin{array}{c}-0.673 \\
(0.125)^{\star \star}\end{array}$ & $\begin{array}{c}-0.695 \\
(0.123)^{\star \star}\end{array}$ & $\begin{array}{l}-1.141 \\
(1.311)\end{array}$ & $\begin{array}{l}-1.166 \\
(1.341)\end{array}$ & $\begin{array}{l}-0.525 \\
(0.601)\end{array}$ & $\begin{array}{l}-0.568 \\
(0.605)\end{array}$ \\
\hline $\begin{array}{c}\text { SRPHST } x \text { Private } x \\
\text { Vocational }\end{array}$ & $\begin{array}{l}-0.785 \\
(0.222)^{\star \star}\end{array}$ & $\begin{array}{l}-0.809 \\
(0.229)^{\star \star}\end{array}$ & $\begin{array}{l}-0.569 \\
(0.879)\end{array}$ & $\begin{array}{l}-0.553 \\
(0.925)\end{array}$ & $\begin{array}{c}0.106 \\
(1.405)\end{array}$ & $\begin{array}{c}0.186 \\
(1.406)\end{array}$ & $\begin{array}{c}-2.214 \\
(0.691)^{\star \star}\end{array}$ & $\begin{array}{c}-2.063 \\
(0.689)^{\star \star}\end{array}$ \\
\hline Private (dummy) & $\begin{array}{c}0.014 \\
(0.005)^{\star}\end{array}$ & $\begin{array}{c}0.014 \\
(0.005)^{\star}\end{array}$ & & & $\begin{array}{c}0.010 \\
(0.012)\end{array}$ & $\begin{array}{c}0.009 \\
(0.012)\end{array}$ & & \\
\hline $\begin{array}{l}\text { Vocational Track } \\
\text { (dummy) }\end{array}$ & $\begin{array}{c}-0.006 \\
(0.002)^{*}\end{array}$ & $\begin{array}{c}-0.006 \\
(0.002)^{*}\end{array}$ & & & $\begin{array}{c}0.006 \\
(0.009)\end{array}$ & $\begin{array}{l}0.006 \\
(0.010)\end{array}$ & & \\
\hline Private $x$ Vocational & $\begin{array}{c}0.018 \\
(0.004)^{\star *}\end{array}$ & $\begin{array}{c}0.018 \\
(0.004)^{\star \star}\end{array}$ & & & $\begin{array}{c}0.010 \\
(0.015)\end{array}$ & $\begin{array}{c}0.010 \\
(0.015)\end{array}$ & & \\
\hline Year control & yes & yes & Yes & yes & yes & yes & yes & yes \\
\hline Prefecture control & yes & yes & & & yes & yes & & \\
\hline Year x Prefecture & & yes & & yes & & yes & & yes \\
\hline $\mathrm{N}$ & 13464 & 13464 & 13401 & 13401 & 13464 & 13464 & 13401 & 13401 \\
\hline $\mathrm{R}^{2}$ & 0.30 & 0.31 & 0.67 & 0.68 & 0.29 & 0.30 & 0.02 & 0.03 \\
\hline
\end{tabular}

Note: Dependent variable is the two-grade pooled dropout rates (\%). The measure of the SRPHST is the expected amount of the grant per recipients in 1 million yen. Columns (3), (4), (7), and (8) control for group fixed-effects for each track. All regressions are weighted by grade 1 and 2 enrollment for each year. Clustered-robust standard errors at prefecture level are shown in parentheses. Instruments used in Columns (5)-(8) are the ratio of private kindergarten subsidies to public ones by prefecture and year. Significance level: **1\%. *5\%. 